\title{
Particular Aspects of Fruit Farming in the Southeast of Poiana Ruscă Mountains
}

\author{
Gheorghe-Gavrilă HOGNOGI, Ana-Maria POP*, Pompei COCEAN, Alexandra-Camelia POTRA, Nicoleta \\ DAVID, Lelia PAPP
}

Faculty of Geography, Centre for Regional Geography, Babeș-Bolyai University of Cluj-Napoca, 5-7 Clinicilor Street, Romania.

* corresponding author: ana-maria.pop@ubbcluj.ro

Bulletin UASVM Horticulture 75(1) / 2018

Print ISSN 1843-5262, Electronic ISSN 1843-536X

DOI:10.15835/buasvmcn-hort: 004917

\begin{abstract}
Alike some other territories in Transylvania, the area of Poiana Ruscă Mountains has been cultivated with fruit trees and vines, benefiting from favourable morphological, soil and climatic conditions. The purpose of our paper was to highlight the particularities of this representative occupation carried out by the local communities in the analyzed area. Through cartographic reconstructions we observed the diachronic evolution of the areas occupied with orchards and the valorisation and management of fruit products. Results confirmed that, despite the significant decline in fruit farming, the abandonment of orchards or the disappearance of nurseries, we can still find some local initiatives encouraging the practice of fruit growing.
\end{abstract}

Keywords: Poiana Ruscă Mountains, fruit farming, Hațeg Depression, orchards, cartographic representations

\section{Introduction}

In Romania, the cultivation of fruit trees and vines dates back to the early antiquity, these two sub-branches of agriculture being part of the concerns and achievements of the Dacian civilization. The significant extension and diversity of cultural landscapes resulting from the human action on soil in order to obtain the necessary vegetable products are irrefutable proofs (Cocean and David, 2014).

Although of great tradition and with a strong development during the communist period, fruit farming has also suffered from the major preponderantly restrictive consequences of the changes in the Romanian economy after 1990. The phenomenon of national des-agriculturalization, physical "desertification" of the rural space and the quasi-total disappearance of the rural social economy, represented by the various occupations and crafts that exploited the local products in situ (Otiman, 2012) massively affected the Depression of Haţeg, namely the villages under study. The destruction of the old fruit farms and the restitution of plots to the former landowners caused land fragmentation, whereas and the change of land use practically resulted in the destruction of large portions of orchards mainly cultivated with apple trees, plum trees, pear trees or cherry trees. In this context of fragmentation of the old orchard plots, mechanization and biotechnologization of crops have become increasingly difficult and costly, many owners (growers) not being able to financially support the modernization of their farms, subsequently resulting in a significant decrease in productivity and efficiency of this agricultural practice.

Along this obvious decline (Ministry of Agriculture and Rural Development, 2015) in the recent years, there have been some initiatives for slight recovery, mainly focused on the development of agriculture in rural areas, financially supported by the European programs (namely the National Rural Development Program 2014-2020). The 
increasing trend in organic products consumption has quite resuscitated the traditional fruit processing within the households owning fruit crops (fruit farms). The production of jams, canned fruit and even alcohol also contributes to the establishment of local brands (i.e. "brandy of Răchitova") which will further stimulate the trade and make this occupation more efficient. On the other hand, although we can find numerous raw products (namely apples) on the Romanian commercial market, they are still predominantly imported (Dan et al., 2015).

At the national level, the fruit sector has become a development priority and was addressed by the NRDP 2014-2020 as part of a sub-program aiming to encourage actions focusing on the following: setting up new fruit farms, develop new orchards maintenance techniques or initiate some forms of cooperation based on European funding (Ministry of Agriculture and Rural Development, 2015). Once with the integration of Romania into the European Union as a Member State, complying with the policies on nature conservation implemented at the European level, some parts of agricultural land tend to disappear, especially those poorly traditionally and intensively exploited. The concept of agriculture practiced on High Nature Value Farmlands (HNVF) has emerged in the 1990s being today included in the Common Agricultural Policy as a criterion for the selection and distribution of some funding. The HNVF represent those lands with natural and semi-natural vegetation (pastures), vegetation harvested by animal husbandry or mowing without the use of fertilizers or other incisive treatments (Keenleyside et al., 2014). According to the estimates of the specialists from the European Environmental Policy Institute, the most extensive HNVF are found in Spain, Romania, Hungary and Poland.

In Romania, the HNVF occupy approximately $30 \%$ of the total agricultural land (5 million hectares) mainly located in Transylvania, Maramureş and Northern Oltenia (Ministry of Agriculture and Rural Development, 2016). Almost the same values $(4,860,372 \mathrm{ha})$ were also validated by the experts of the European Environment Agency (Paracchini et al., 2008). As identified by the experts of a joint project, among the benefits of HNVF we mention: rural vitality, high productivity of small farms compared to large farms, food security, the existence of natural predators for natural pest control (ADEPT Foundation, 2016). On the other hand, the very low productivity of HNVF makes them the perfect example for biodiversity preservation (Poux and Ramain, 2009).

Fruit growing may have broad resurrection prospects, being able to provide quality products and cover the needs not only of the local population but also of the neighbouring regions, which are less productive in this respect. Thus, fruit growing practices may even overcome the standards and efficiency recorded in the decades prior to transition.

The purpose of our research was to identify the diachronic peculiarities of fruit farming in the southeastern area of the Poiana Ruscă Mountains and how this practice could be further developed. The paper is structured in several sequences: the first one reveals the research topic and the conceptual framework; the second presents the methodology used; the third sequence shows the results of the study, as follows: firstly, we present the evolution of the fruit farming land as resulted from the cause-effect analysis, followed by the identification of current dysfunctions based on the diagnosis, and secondly, we analyze the future options of the local communities to valorise and manage orchards; in the last sequence we try to conclusively identify the directions for the development of fruit growing activities in Haţeg Depression.

\section{Materials and methods}

We studied the southeast area of the Poiana Ruscă Mountains, in Hunedoara County, consisting of 6 territorial administrative units (TAUs) (Haţeg, Răchitova, Densuş, General Berthelot, Sarmizegetusa, and Totești) on which territory we found the highest concentration of slopes cultivated with fruit trees. A distinct feature of the studied area is the harmonious combination of physical-geographic conditions, the territory overlapping the classical intra-mountainous depression of Haţeg (Hognogi, 2016). The area is highly flattened, with deep deposits of sediments, the western part being characterized by mild and moderate slopes, south-east oriented, with great sun exposure. The soil substrate consists mainly of luvisoils, cambisoils and spodosoils, with wellstructured horizons and rather largely extended, 


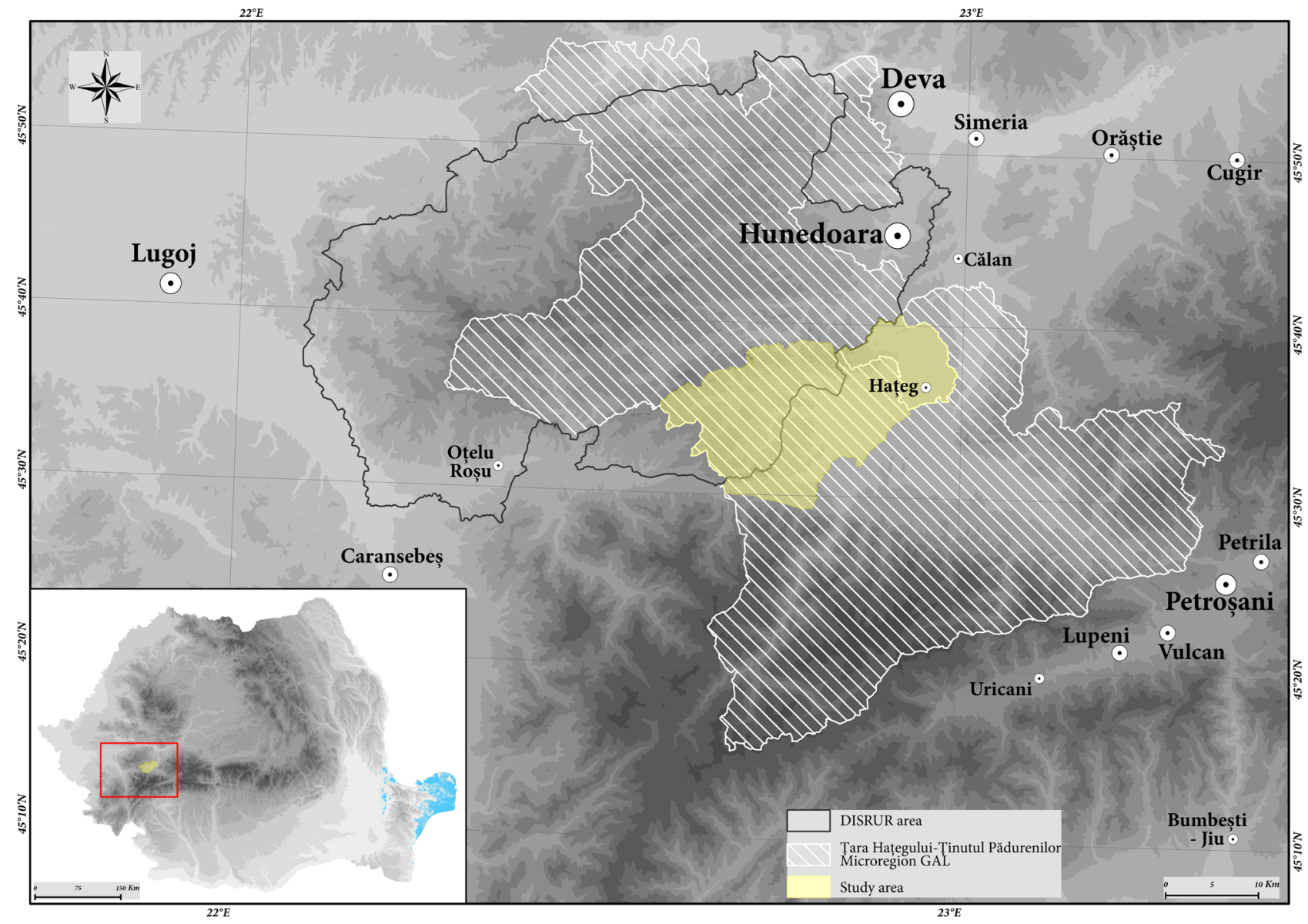

Figure 1. The study area

which, especially in the case of the first class, makes them suitable for an optimal cultivation of the plants of the category mentioned above.

The location of the TAUs in an intramountainous area (massifs of Retezat, Poiana Ruscă and Şureanu) makes them shape a quasiclosed space, with typical shelter climate, protected from strong winds and climatic extremes that usually bring phenological risks and vulnerabilities. The protective climate may also be supported by "a foehn wind suspected to be present on the southwestern slopes of Poiana Ruscă Mountains (Hognogi and Văidean, 2015).

The analysed area is included into the Local Action Group LAG - Microregion "Land of
Pădureni - Land of Hațeg", but it is also part of the mountainous region (generally overlapping Poiana Ruscă Mountains) subject to DISRUR Project (Demographic Disparities in Rural Areas), financed by the PN III Programme/Subprogram 3.1. Bilateral/ multilateral/Module AUF-RO.

Methodologically, we carried out the chronological analysis of plots occupied by orchards based on cartographic reconstruction (Tab. 1).

Data processing implied the creation of evolutionary cartographic representations, validated by field documentation in the investigated localities, between June and July 2016. The data on the valorisation of fruit growing

Table 1. Cartographic resources used for orchard analysis

\begin{tabular}{cr}
\hline Analyzed period & Cartographic resources employed \\
\hline $806-1869$ & The second Habsburg topographic survey, scale 1:25,000 \\
\hline 1940 & The Soviet military map, scale 1:50,000 \\
\hline 1978 & The topographic map of Romania, scale $1: 25,000$ \\
\hline 2015 & Agency of Payments and Intervention in Agriculture (APIA) \\
\hline
\end{tabular}


in Haţeg Depression were collected during the field work carried out in June-July 2016.

\section{Results and discussions \\ a) The diachronic exploitation of fruit growing farms}

Fruit growing strictly depends on soil patterns, certain relief and climatic factors, plus the anthropogenic ones, such as: age and high density of population, tradition of occupations, technological equipment, etc. The archaeological remains found in the Cioclovina Cave attest habitation in the Haţeg Depression even from the Palaeolithic period, whereas the Hallstatt treasure deposit discovered in the same cave shows an intensification of inhabitation in the Mesolithic and Neolithic ages. The location of the capital of Dacia - Sarmizegetusa Regia in the Mountains of Orăştie and the capital of the future Roman province at Sarmizegetusa Ulpia Traiana (Romanian Academy, 2001) confirms the role of Haţeg Depression as a "central place" within the inhabited Danubian-Pontic-Carpathian space. Consequently, its anthropogenic evolution is old and intense, whereas agriculture, including fruit farming, represents a fundamental existential support for it.

In order to determine the evolution of areas occupied with fruit crops, several representative cartographic sources were used, both at regional and local level. At the regional level (the southeast area of Poiana Ruscă Mountains) we started from the historical reconstruction of the data recorded on the Topographic Map of Romania and the data provided by the Agency for Payments and Intervention in Agriculture (APIA) of Hunedoara County to observe the evolution of slopes occupied with fruit crops. However, at the local scale (Densuş locality) we mainly used two older cartographic sources (the Second Habsburg topographic survey sheet and the Soviet Military Map). The additional examination at the local level aimed to reveal the continuity and the favourability of this agricultural practice. Much more, the poor graphical quality of the first two cartographic resources did not allow for the vectorization of orchard areas across the administrative territory of all the investigated TAUs.

Thus, in 1978, there was recorded an area of 296.38 ha occupied by fruit trees, with more compact plots on the administrative territory of the villages of Răchitova, Fărcădin and Silvașu de Jos (Tab. 2, Fig. 2). We note the predominance of plum crops, especially in the villages of Densuș, Sarmizegetusa, General Berthelot and Răchitova (mixed with apple and cherry), apple crops in Densuş and Hațeg, the fresh produce being used by the canned fruit and vegetable factory in Hațeg. The collectivization of villages, followed by the privatization of the urban enterprises and the restitution of some plots (including orchards) to the descendants of some former owners, resulted

Table 2. The share of areas occupied with orchards in the analyzed area, in 1974

\begin{tabular}{|c|c|c|c|c|c|c|c|}
\hline \multirow{2}{*}{$\begin{array}{l}\text { Permanent } \\
\text { crops }\end{array}$} & \multicolumn{7}{|c|}{ TAU } \\
\hline & Densuş & $\begin{array}{c}\text { General } \\
\text { Berthelot }\end{array}$ & Hațeg & Răchitova & Sarmizegetusa & Toteşti & Total (ha) \\
\hline Plum tree & 611.4 & 428.1 & 148.0 & & 285.9 & 49.0 & 1522.4 \\
\hline Apple tree & 278.7 & 35.4 & 127.2 & 10.7 & 47.1 & 132.1 & 631.1 \\
\hline $\begin{array}{l}\text { Plum tree, apple } \\
\text { tree, cherry tree }\end{array}$ & & & 52.3 & 540.9 & & & 593.2 \\
\hline Pear & 43.5 & & & & & & 43.5 \\
\hline Quincy & & & & & & 6.4 & 6.4 \\
\hline Sweet cherry & & & 13.8 & & & & 13.8 \\
\hline Cherry & & 22.1 & 0.2 & & & & 22.3 \\
\hline Blackcurrant & 5.4 & & 5.9 & & & & 11.3 \\
\hline Vine & & & 119.8 & & & & 119.8 \\
\hline Total (ha) & 939.0 & 485.6 & 467.2 & 551.5 & 333.0 & 187.4 & 2963.8 \\
\hline
\end{tabular}




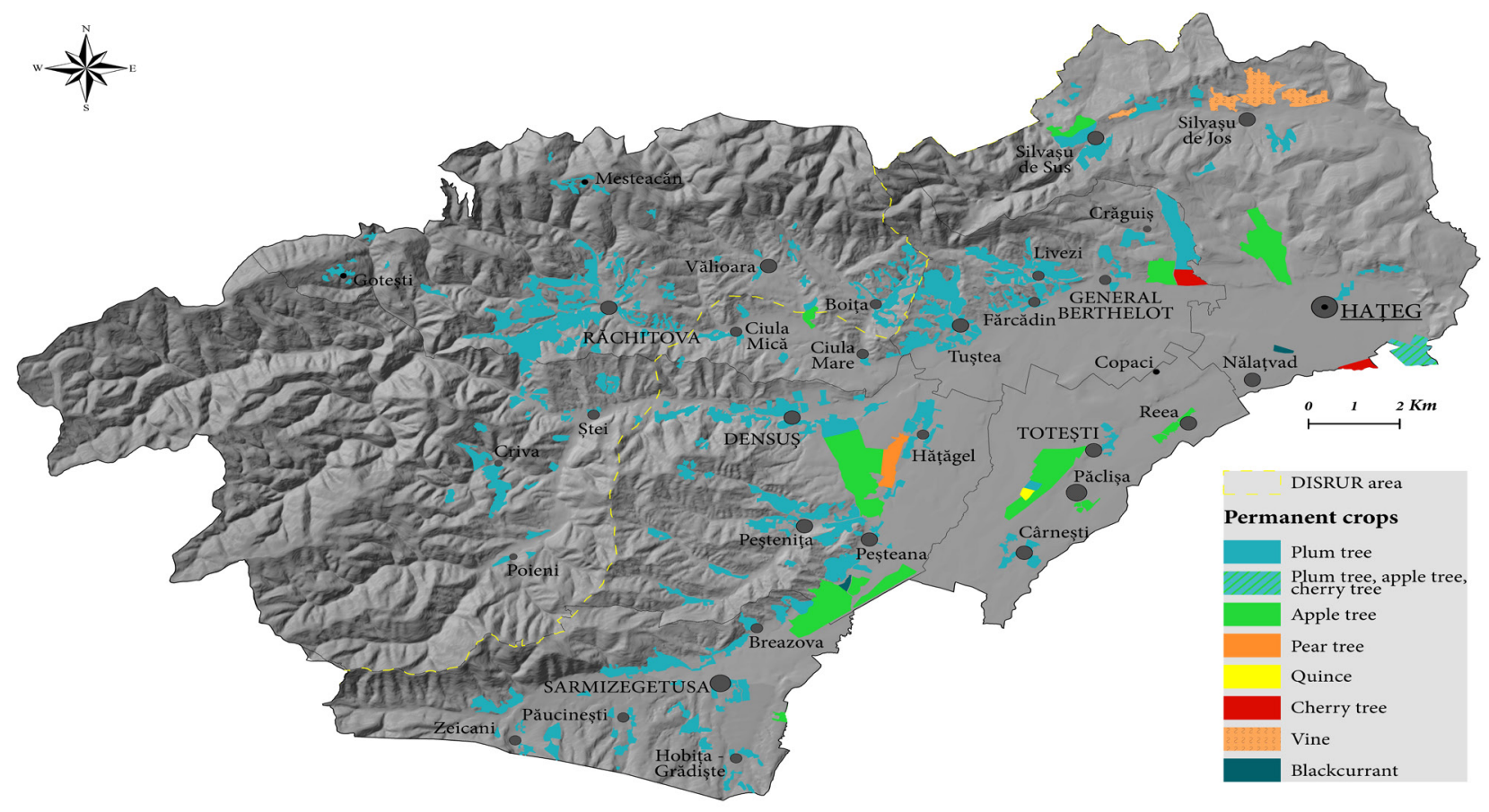

Figure 2. Spatial distribution of fruit farms, according to the topographic map of Romania

in a severe degree of fragmentation of agricultural land. Subsequently, orchards could no longer be financially maintained and the produce (raw-fresh fruit or processed/canned - juice, brandy, jam, etc.) could no longer be sold on the local market. Unfortunately, not even the national legislative framework was able to encourage the development of fruit growing activities. For instance, in the case of Răchitova village, which was not affected by collectivisation, the restraint of fruit-growing activities was an effect of individual actions, less organized than the socialist policies, and quite significantly influenced by the high fragmentation of slopes.

A distinct situation of the same slopes occupied by fruit trees results from the data

Table 3. The share of areas occupied with orchards in the analysed area, in 2015

\begin{tabular}{cccccccc}
\hline \multirow{2}{*}{$\begin{array}{c}\text { Permanent } \\
\text { crops }\end{array}$} & Densuş & $\begin{array}{c}\text { General } \\
\text { Berthelot }\end{array}$ & Hațeg & Răchitova & Sarmizegetusa & Toteşti & Total (ha) \\
\cline { 2 - 8 } & 86.8 & 27.0 & 34.7 & 33.4 & 14.5 & 5.8 & 202.2 \\
\hline Plum tree & 11.8 & 13.5 & 7.4 & 5.7 & 1.7 & 83.3 \\
\hline Apple tree & 43.2 & & 0.5 & & 0.8 & 1.2 \\
\hline $\begin{array}{c}\text { Walnut and } \\
\text { hazelnut }\end{array}$ & & 0.3 & 0.1 & & 0.1 & & 5.7 \\
\hline $\begin{array}{c}\text { Other fruit trees } \\
\text { Traditional } \\
\text { pasture } \\
\text { with orchards }\end{array}$ & 5.2 & 183.9 & 122.9 & 250.2 & 118.5 & 44.3 & 1026.3 \\
\hline $\begin{array}{c}\text { Raspberry } \\
\text { Blackcurrant }\end{array}$ & 0.2 & 0.4 & & & & 0.4 \\
\hline Total (ha) & 441.7 & 223.0 & 171.6 & 291.4 & 138.9 & 52.9 & 1319.6 \\
\hline
\end{tabular}




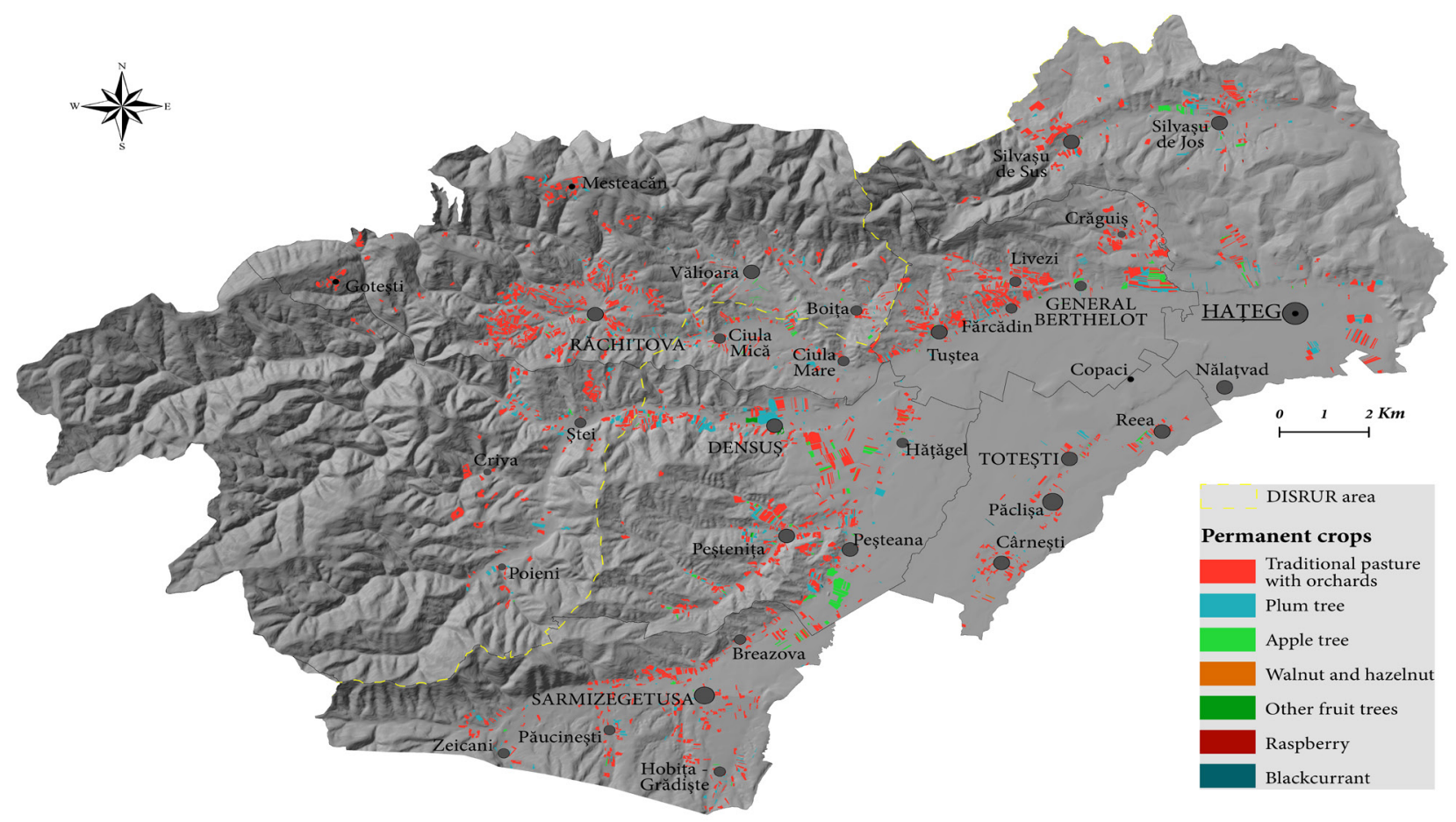

Figure 3. Spatial distribution of fruit farms according to APIA (2015)

provided by APIA (2015) which illustrate that the total area occupied by orchards already decreased by half (1319.6 ha) (Tab. 3, Fig. 3). We also note that this decreasing trend is even more pronounced in the case of individual farms, due to the aging and poor maintenance of orchards, the fragmentation of the individual farms, facts mostly determined by the aging of the growers (over 60 years old individuals) and the lack of financial capital needed for investments. Plum crops have been the most competitive and are still located in the same areas, although more scattered spatially, followed by apple and cherry crops. However, we can currently notice a change in land use, data showing an increase in the size of pastures with orchards (1026.3 ha) which further strengthens the idea of orchard degradation.

Densuș village is considered a representative settlement for Hunedoara area, mainly due to the economic role played by orchards (namely plum crops). In this case, the map reconstruction based on the 4 cartographic resources reveals an ascending evolution during the Habsburg and socialist periods.

During the rule of the Austro-Hungarian Empire, the first large fruit farms were established, located along the main communication axis, in the vicinity of the individual households or in their backyards. The onset of socialism reveals the maintenance of an approximately equal surface of orchards, but much more concentrated and intensively cultivated. Thus, by the mid of collectivization period fruit farms reached their maximum size. Later on, the change of owners and the segmentation of plots resulted in a visible fragmentation of orchards and an insertion of some pasture plots among them. The subsidies from APIA have made many of the orchard owners to declare these plots as pastures, based on the fact that many of the fruit tree crops were already aged and unproductive.

\section{b) Operational measures for the valorisation and management of orchards}

Regarding the rehabilitation of orchards we identified several funding opportunities under the National Rural Development Program 2014-2020, which allows for the development of fruit growing practices to be directly funded, by applying several operational programme measures such as:

Sub-measure 4.1a "Investments in fruit farms"; 

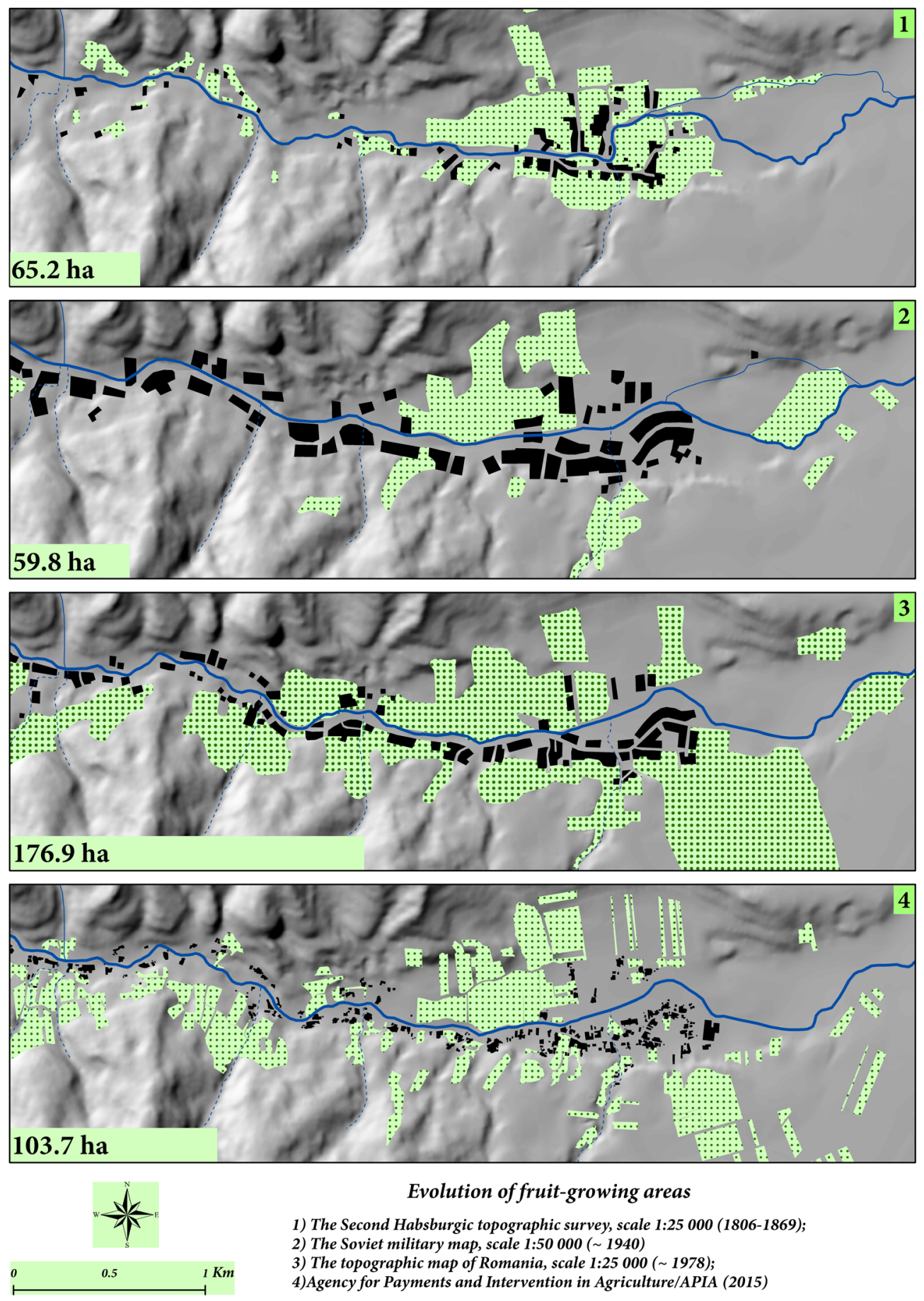

\section{Evolution of fruit-growing areas}

1) The Second Habsburgic topographic survey, scale 1:25 000 (1806-1869); 2) The Soviet military map, scale 1:50 $000(\sim 1940)$

3) The topographic map of Romania, scale 1:25 000 ( 1978);

4)Agency for Payments and Intervention in Agriculture/APIA (2015)

Figure 4. The diachronic evolution of orchards in Densuş village

Sub-measure $4.2 \mathrm{a}$ "Investments in the processing/marketing of products in the fruit sector";

Sub-measure 9.1a "Setting up producer groups in the fruit growing sector";

Sub-measure 16.1a "Support for setting up and functioning of Operational Groups (OGs) for the development of pilot projects, new products, practices, processes and technologies in the fruit growing sector".

According to Annex 7 of the fruit growing thematic sub-program - sub-measure $4.2 \mathrm{a}$, the analyzed TAUs show natural favourability for plum, apple, walnut, walnut, cherry crops and increased favourability based on irrigation for strawberry, currant and almond crops. 
Under the three environmental and climate measures of the NRDP 2014-2020 (M.10 Agrienvironment and Climate, M.11 Organic farming and M.13 Areas affected by natural constraints) farmers were allocated about 9.476 mil. EUR for the support of agriculture. Out of the 8 packages of Measure 10 - Agri-environment and Climate, the first two packages (Package 1 - High nature value grasslands, Package 2 - Traditional farming practices) are addressed to farmers who use agricultural land, who will be granted yearly compensatory payments for a period of 5 years. High-value grasslands also include traditional orchards that are used as permanent grasslands through mowing and/or grazing.

As for eligibility criteria, it is compulsory for farmers to own a minimum 1 hectare farm, whilst for sustainable orchards the plots must be of at least 0.3 ha (Ministry of Agriculture and Rural Development, 2016). However, this dimensioning is considered questionable since there is no correlation between the size of the farm and the high natural value of the land (Beaufoy et al., 2008). Villages located in the southeast part of the Poiana Ruscă Mountains, perceived as TAU LAU 2 (Local Administrative Unit) are all eligible for this type of funding (at national level, 998 TAUs are eligible for this package).

\section{Conclusion}

The long tradition of cultivating some fruitgrowing areas can be revitalized individually or in association by benefitting from funding schemes designed to support farmers' investments. Setting up producer networks and regulating the legal framework by encouraging the trade of the Romanian fruit products can also represent other development directions that stakeholders in the fruit growing sector can take into account.

On the other hand, the preservation of orchards is one step, which is one of the European actions aimed to encourage the preservation of biodiversity, fruit farms becoming independent cultural landscapes.

Acknowledgements. This study reveals some of the results achieved through the project DISRUR/14-AUF: "Demographic Disparities in Rural Areas". Writing this paper was possible due to the financial support provided under the PN
III Programme/Sub-programme 3.1. Bilateral/ multilateral/Module AUF-RO.

\section{References}

1. Academia Română (2001). Istoria Românilor. București: Editura Enciclopedică.

2. Beaufoy G, Jones G, De Rijk K, Kazakova Y (2008). High Nature Value Farmlands: Recognising the Importance of South East European Landscapes. WWF DanubeCarpathian Programme and European Forum on Nature Conservation and Pastoralism.

3. Cocean P, David N (2014). Peisaje culturale. Cluj-Napoca: Risoprint.

4. Dan C, Şerban C, Sestras AF, Militaru M, Morariu P, Sestras RE (2015). Consumer Perception concerning Apple Fruit Quality, Depending on Cultivars and Hedonic Scale of Evaluation - a Case Study. Notulae Scientia Biologicae, 7(1), 140-149, DOI: 0.15835/nsb.7.1.9553.

5. Fundația ADEPT Transilvania (2016), Dezvoltare rurală și terenuri agricole cu înaltă valoare naturală, WWFRomânia, ProPark - Fundaţia pentru Arii Protejate.

6. Hognogi GG (2016). Țara Hațegului. Studiu de geografie regională. Cluj-Napoca: Risoprint.

7. Hognogi GG, Văidean R (2015). Relevant Hydrology Elements in term of Regional Geography Analysis. Case Study: The Land of Haţeg. Studia Geographia UBB, 2, 113120.

8. Keenleyside C, Beaufoy G, Tucker G, Jones G (2014). High Nature Value farming throughout EU-27 and its financial support under the CAP. Institute for European Environmental Policy, European Union, final report, Luxembourg.

9. Ministerul Agriculturii şi Dezvoltării Rurale (2015). Strategia pentru dezvoltarea sectorului agroalimentar pe teremen mediu şi lung. Orizont 2020-2030, București.

10. Ministerul Agriculturii şi Dezvoltării Rurale (2016). Ghid informativ pentru beneficiarii măsurilor de mediu şi climă ale Programului Naţional de Dezvolrare Rurală (PNDR) 2014-2020, Direcția Generală Dezvoltare Rurală - Autoritate de management pentru PDR, București.

11. Otiman IP (2012). Structura agrară actuală a României o mare (şi nerezolvată) problemă socială şi economică a țării, Revista Română de Sociologie. 5-6: 339-360.

12. Paracchini ML, Petersen JE, Hoogeeven Y, Bamps C, Burfield I, Swaay C (2008). High Nature Value Farmland in Europe. An estimate of the distribution patterns on the basis of land cover and biodiversity data. European Environment Agency, European Communities, Ispra, Italia.

13. Poux X, Ramain B (2009). L'agriculture à Haute Valeur Naturelle: mieux la (re)connaître pour mieux l'accompagner. European Forum on Nature Conservation and Pastoralism. 